\title{
İlk Dönem Sovyet Bürokrasisinde Yahudi Mevcudiyeti
}

\author{
Araștırma makalesi / Research article
}

\section{Şir Muhammed DUALI*}

Jewish Availability in the First Period on Soviet Bureaucracy

Citation/@: Dualı, Şir Muhammed, (2020). Jewish Availability in the First Period on Soviet Bureaucracy, Milel ve Nihal, 17 (1), 45-59.

Abstract: Almost every socio-political transformation that over the place in history gains importance with whom and for what purposes this transformation is realized. Therefore, it will be possible to reach correct conclusions when it is evaluated within the framework of the Bolshevik Revolution of 25 October 1917, which brought the end of the Tsarist regime, and the goals and objectives of the cadres who realized this revolution. In fact, the Bolshevik Revolution and the ethnic roots of high-ranking personalities who played an active role in this process have been an issue that has been debated for a long time. In particular, the researchers who try to show that the Bolshevik Revolution is organized by external forces draw note to the presence of hundreds of Jews in the staff that carried out the revolution. On the other hand, Jewish researchers working on the subject accept the role played by the Jews in the revolution, but they emphasize that these people are 'renegade'. According to them, these people have nothing to do with Judaism. This article focuses on Jewish bureaucrats, who played an active role in the establishment of the Soviet Union. In this framework show up the active role played by Jewish persons in the process of establishing the Soviets is revealed. Also, on bureaucracy, however, the reflections of the current Jewish power on Russian society are addressed and the process of forming the Jewish autonomous region (Birobidzhan) is shed light on.

Keywords: Soviet Union, Jews, Bureaucracy, Autonomy, Birobidzhan.

* Doç. Dr., Tokat Gaziosmanpaşa Üniversitesi İlahiyat Fakültesi, Din Bilimleri Anabilim Dalı [muhammed.duali@gop.edu.tr] ORCID: 0000-0003-0136-1214. 
Atıf/C: Dualı, Şir Muhammed, (2020). İlk Dönem Sovyet Bürokrasisinde Yahudi Mevcudiyeti, Milel ve Nihal, 17 (1), 45-59.

Öz: Tarihte meydana gelen hemen her sosyo-politik dönüşüm, bu dönüşümün kimler tarafından ve hangi amaçlar uğruna gerçekleştirdiğine bağlı olarak anlam kazanmaktadır. Dolayısıyla Çarlık rejiminin sonunu getiren 1917 Şubat Devrimi ve onun doğurduğu 25 Ekim Bolşevik Devrimi, bu devrimleri gerçekleştiren kadroların amaç ve hedefleri çerçevesinde değerlendirildiğinde doğru sonuçlara ulaşmak mümkün olacaktır. Esasında Bolşevik Devrimi ve bu süreçte aktif rol üstlenen üst düzey şahsiyetlerin etnik kökenleri, öteden beri tartışılagelen bir husustur. Özellikle Bolşevik Devriminin dış güçlerce örgütlendiğini ortaya koymaya çalışan araştırmacılar, devrimi gerçekleştiren kadroda yer alan yüzlerce Yahudi'ye dikkat çekmekteler. Diğer taraftan konu ile ilgili çalışma yapan Yahudi araştırmacılar devrimde Yahudilerin oynadığı rolü kabul etmekle birlikte bu şahısların dinden çıkan kişiler oldukları üzerinde durmak suretiyle konunun Yahudilikle bir ilgisinin olmadığını belirtmeye çalışmaktalar. Bu makale, Sovyetler Birliği’nin tesisinde etkin rol üstlenen Yahudi bürokratlar ve görev aldıkları kurumlar üzerinde durmaktadır. Bu çerçevede Sovyetlerin tesisi sürecinde Yahudi kökenli şahsiyetlerin oynadıkları etkin rol gözler önüne serilmeye çalışılacaktır. Bununla birlikte devletin üst kademelerinde mevcut Yahudi etkinliğinin Rus toplumu üzerindeki yansımaları ele alınmakta ve Yahudi özerk bölgesinin (Birobican) oluşturulması sürecine ışık tutulmaktadır.

Anahtar Kelimeler: Sovyetler Birliği, Yahudiler, Bürokrasi, Özerklik, Birobican.

\section{Giriş}

Tarihsel süreç içerisinde Yahudilerin Rus yönetimi altında yaşamalarının ilk örneklerine 10 ve 11. yüzyıllarda rastlamak mümkündür. Ancak Rusların Yahudi toplumu ile imtihanı 1772-1794 yılları arasında Polonya'nın Rusya'nın kontrolü altına girmesi ile başladı. Zira Polonya topraklarında yüzbinlerce Yahudi yaşamaktaydı ve bu işgal ile birlikte Yahudi nüfus da Rusya yönetimi altına girmiş oldu. Ortodoks Rusların, Tanrı katili olarak suçladıkları Yahudilere bakış açıları oldukça kötü idi. Bu nedenle Yahudiler Rus yönetimi altında zorunlu iskân sınırları içerisine hapsedildiler ve ilk başlarda Rus toplumuna karışıp kaynaşmalarına müsaade edilmedi. Ancak 1800 'lü yılların ortalarından itibaren tecrit politikaları yerini, Yahudilerin Rus toplumu içerisinde asimile edilmesi düşüncesine bıraktı. $\mathrm{Bu}$ çerçevede Yahudi gençler, Rus dil ve kültürünü öğrenmeleri, Rus okullarında eğitim almaları hususunda teşvik edildiler. Rus yönetimi altındaki Yahudiler ilk aşamada asimilasyon politikalarına direndiyseler de Batıda başlayan aydınlanma ve onun Yahudi toplumundaki karşılığı olan Haskala hareketi ile bu direnç önemli öl- 
çüde ortadan kaldırılmış oldu. Artık Yahudiler Moskova ve Petersburg başta olmak üzere Rusya'nın önemli üniversitelerinde tahsil görüyor, çeşitli fikri ve siyasi oluşumlarda yer alabiliyorlardı. Ancak Yahudilerin kısa bir zaman diliminde Rus eğitim, ekonomi ve sanat alanlarında etkin olmaya başlamaları, Rus devletinin yeni bazı kısıtlayıcı tedbirler almasına neden oldu. Artık Yahudi gençler için eğitim ve çalışma alanında kota uygulanması söz konusu olmuştu. Ruslar bu sayede toplumun çeşitli kademelerinde giderek artan Yahudi etkinliğini minimize etmeyi amaçliyordu. Bu baskılar karşısında örgütlenme yoluna giden Yahudi gençler, çeşitli anarşist oluşumlar içerisinde yer almaya ve rejime karşı faaliyetlerde bulunmaya başladılar.

Rejimin Yahudilere yönelik şiddete başvurmasının başlangıcı ise 1881 yılıdır. Zira Çar II. Aleksandr Nikolayeviç'in (1818-1881) uğradığı suikast, içerisinde Yahudi gençlerin de aktif rol aldığı bir anarşist grup tarafından gerçekleştirilmişti. Bu tarihten itibaren Çarlık rejimi, Yahudi toplumuna yönelik baskı ve şiddet politikalarını artırarak devam ettirdi. Tarihe "pogromlar" olarak geçen bu süreçte on binlerce Yahudi katledilirken, yüz binlercesi de Rusya'yı terk ederek başta ABD olmak üzere birden fazla ülkeye göç etmek zorunda bırakıldı. Yahudi anarşist oluşumların ve rejim karşıtı işçi teşkilatların bitmez tükenmez mücadeleleri neticesinde, Çar II. Nikolay Aleksandroviç Romanov (1868-1918) Mart 1917 tarihinde tahttan çekildiğini beyan etti ve böylelikle Çarlık döneminin de sonu gelmiş oldu. Çarlık rejimini ortadan kaldıran devrimciler Geçici Hükümet adı altında yeni bir yönetim oluşturdular. Ancak aynı yılın Ekim ayına gelindiğinde Vladimir Lenin (1870-1924) önderliğindeki Bolşevik Partisi, ikinci bir devrim ile ülkenin yönetimini ele geçirmeyi başardı ve artık Rusya tarihinde yeni bir dönem, Bolşevizm Dönemi başlamış oldu. Bolşevikler ve devleti oluşturan öncül kadrolar kimlerdi ve nasıl bir devlet/sistem kurmayı amaçlıyorlardı ve Bolşeviklerin tepe isimleri kimlerden müteşekkildi? Şimdi bu sorulara yanıt bulmaya çalışalım.

\section{1918-1938 Yılları Arasında Sovyet Bürokrasisinde Yahudi Var- l1ğ1}

1917 Mart ayı itibarıyla oluşturulan Geçici Hükümetin görevde bulunduğu zaman diliminde Rusya'da faaliyet yürüten dört önemli partiden söz etmek mümkündür. Bunlardan birincisi Sosyalist-Devrimciler Partisidir. İkincisi Sosyal Demokrat Bolşevik Partisidir ki bu 
süreçte devlet kademelerinde etkinliği Menşeviklere kaptırmışlardır. Üçüncü ve Geçici Hükümeti oluşturan parti ise Sosyal Demokrat Menşevik Partisidir. Son olarak da üyelerinin nerede ise tamamı Yahudilerden oluşan BUND (Genel Yahudi Emek Federasyonu) Partisi gelmektedir. BUND Partisi dışında ismi belirtilen siyasi partilerin de hemen tümünde ortalama \%60 civarında Yahudi etkinliği söz konusudur. ${ }^{1} \mathrm{Bu}$ oran göz önünde bulundurulduğunda, iktidar hangi partinin eline geçerse geçsin aslında kazananın yine Yahudiler olacağı aşikârdır. Yahudilerin Devrim hareketi ve sonrasında bu denli etkin olmalarının temelinde ise bu hususta ciddi deneyime sahibi olmaları yatmaktadır. Bilindiği üzere 1800 'lü yıllardan beri ortaya çıkan Çarlık karşıtı ayaklanmalarda Yahudiler önemli rol oynamışlardır. Ayrıca devrimin hemen öncesi ABD'ye kaçan ve orada örgütlenen başta Lev Troçki (1897-1940) olmak üzere binlerce Yahudi devrimle birlikte yeniden Rusya'ya dönmüşler ve Sovyetlerin inşasında önemli rol üstlenmişlerdir. Bu hakikati dile getiren araştırmacı Andrey Dikiy, 1917 yılının yaz aylarında gerçekleştirilen hemen her miting, şura ve komite toplantılarına ya Yahudilerin öncülük ettiğine ya da çoğunluğun onlardan oluştuğuna dikkat çekmektedir. ${ }^{2}$ Çeşitli devrimci ve anarşist oluşumlar içerisinde varlık gösteren Yahudilerin en etkili ve örgütlü oldukları yer Bolşevik Partisidir. Uzun yıllar Rusya'da kalan ve süreci yakından izleyen Times Gazetesi muhabiri Robert Wilton'un (ö. 1925), Bolşevik Partisi bünyesinde mevcut Yahudi etkinliğine yönelik ortaya koyduğu iddialar dikkatlerden kaçmamaktadır. Wilton'a göre Bolşeviklerin oluşturdukları yönetim kadrosunda görev alan 556 üst düzey bürokrattan 447'si Yahudi kökenli şahıslardan müteşekkildi. Yine 1918'de Petersburg'da var olan 387 üst düzey yönetim kadrosunun sadece 16 's1 etnik Ruslardan, geri kalan $371^{\prime} i$ ise Yahudi asıllı Rus vatandaşlardan ve bunların da 265'i devrim sonrası ABD'den gelen Yahudilerden oluşuyordu. Örneğin Mart 1919'da gerçekleştirilen VIII. Rusya Komünist Parti Kongresinde milletvekillerinin \%16'sı Yahudilerden müteşekkildi. Ayrıca Politbiro'da (Komünist Parti Yönetim

1 Dikiy Andrey, Yevreyi v Rossii I v SSSR, Russko-Yeveyskiy Dialog, Blagovest, (Novosibirsk: 2005) 111.

2 Dikiy, Evreyi v Rossi i SSSR, 125. 
Kurulu) başta Yahudi Troçki ${ }^{3}$ olmak üzere G. S. Zinoviev, L. B. Kamenev ve Y. M. Sverdlov gibi devrimin önde gelen isimleri yer alıyordu. Dikiy, Bolşeviklerin \%75'nin Rusya Yahudilerinden müteşekkil olduğunu belirten 5 Mart 1919 tarihli “Londra Time" gazetesinde yer alan habere dikkat çekmektedir. Muhtemeldir ki burada Bolşevik Partisi üyeleri değil de yönetim kadroları içerisinde yer alan Yahudiler kastedilmektedir. Dolayısıyla bu dönemi araştıran tarihçilerin birçoğuna göre, Ekim Devrimi haddizatında bir 'Yahudi Devrimi' özelliği taşımaktadır. Bu hususu teyit eder mahiyette İngiliz politikacı Winston Churchill'in (ö. 1965) şöyle dediği belirtilmektedir; "Yahudiler Rus halkını ensesinden yakalamış ve pratik olarak devasa imparatorluğun hamisi haline gelmişlerdir. 4" Ayrıca Bolşevik lider Lenin'in devrim sırasında Yahudilerin çok önemli pozisyonlar üslendiklerini ve kritik aşamalarda takındıkları tavırlar nedeniyle devrimi kurtardıklarını belirtmek suretiyle bu kanıyı kuvvetlendirmektedir.

Yahudilerin devlet bürokrasisi içerisinde bu denli etkin olması, bazı araştırmacıları, Bolşevik Devrim önderlerinin Yahudilikten esinlenmiş olabileceği düşüncesine sevk etmiştir. Bu konuda görüş belirten Rus düşünür Nikolay Berdyaev, (ö. 1948) Rusya'da tesis edilen Sosyalizmin aslında Yahudilerin Kral Davut ve Süleyman'ın hükümranlığı dönemlerine olan inançlarının bir yansıması olarak değerlendirmektedir. Berdyaev'e göre Sosyalizm teorisinin banisi Marks'ın Yahudi olması bir rastlantı değildir. Nitekim Yahudi inancına göre, seçilmiş halkı kurtarmak üzere bir kurtarıcının gelmesi beklenmektedir ve Marks'a ${ }^{5}$ göre Tanrı'nın kurtarılmayı bekleyen

3 Anarşist bir Yahudi olan L. Troçki, Devrim öncesi ABD'ye kaçmış ve orada Çarlık rejimi aleyhinde mitingler tertiplemiştir. Devrimle birlikte Rusya'ya dönen binlerce Yahudi arasında yer alan Troçki, Sovyetler Birliği'nin ilk dönemlerinde önemli bir konuma getirilmiştir. Yitzhak Arad, Katastrofa Evreev na Okkupirovannık Territoriyah Sovetskogo Soyuza (1941-1954), Tom I, Tsentr Holokost, (Moskova: 2007), 29.

4 Kozlov, Yevreyi v Rossii-SSSR, s. 139.

5 Aslında (sonradan Protestanlaşan) Yahudi bir ailenin çocuğu olan K. Marx, yaşadığı dönemde yaygınlık kazanan Alman idealist akımıyla Fransız sosyalist akımının ortaya koyduğu Yahudi karşıtlığının etkisi altında kalmıştır. O Yahudilerin aşırı derecede paraya düşkünlüğünü eleştirerek dünyadaki Yahudi'nin inancı pazarlık, Tanrısıysa paradır diyordu. Marx’a göre kötülük sosyal ve ekonomik nedenlerden kaynaklanmaktaydı. Marx her ne kadar Yahudi zihniyetine karşı olsa da ilerleme kavramı çerçevesinde geliştirdiği komünizmin teorisinin kökleri 
seçilmiş ulusu ve kurtarıcıyı bekleyen halkı proletaryadır. ${ }^{6}$ Yine Bolşevik Devrimi konusunda benzer bir yaklaşım sergileyen Vladimir Moss'a göre de Bolşevik Devrimi, Yahudi düşüncesinin bir ürünüdür. O, Rus devriminin ideolojisini ve temel esaslarını Yahudi felsefi tarihinden aldığını, devrim liderlerinin tümünün Yahudi olmamasına rağmen bilinçli veya bilinçsiz bir şekilde eylemlerini bu doğrultuda hayata geçirdiklerini belirtmektedir. Moss, bu hususta devrimi gerçekleştiren kitleler ve özellikle hükümet kanadında aktif olarak rol alan Yahudilere dikkat çekmektedir. Bu konuda istatistiki veriler ortaya koyan Douglas Reed'ten alıntılar yapan Moss, Bolşevik Partisi Merkez Komitesi üyelerinin Lenin dâhil 3'ü Rus ve kalan 9'unun ise Yahudilerden oluştuğunun altını çizmektedir. Yine ikinci önemli devlet organı olan Merkez Yürütme Komitesi 42 Yahudi'ye mukabil 19 Rus, Gürcü ve diğer milletlerin temsilcilerinden oluşuyordu. Halk Komiserleri Konseyi bünyesindeyse 17 Yahudi ve 5 diğer milletlere mensup üye bulunuyordu. ${ }^{7}$ Kisacası yukarıda da zikredildiği üzere yönetim kadrolarında bulunan 556 kişiden 447'si Yahudi soy ismi taşımaktaydı.

1917 ve 1921 yılları arasında Rusya Sosyalist Federatif Cumhuriyeti dönemi Sovyet yönetiminde yer alan Yahudilerin bulundukları konum ve sayıları şu şekildedir;

Tesis edilen yeni rejimin İçişleri Bakanı, Yahudi Yakov Mihailoviç Sverdlov'dur (ö. 1919). Sovyet Silahlı Kuvvetler Komutanlığ görevine Yahudi Lev Troçki (ö. 1940) getirilmiştir. Yarg1 kurumunun başında yine bir Yahudi olan İsak Steinberg (ö. 1957) bulunurken, yeni rejimin ideolojik temellerinin formüle edicisi olarak karş1mıza David Riazanov (ö. 1938) çıkmaktadır. Yine bu dönemde Petersburg'un idaresi Yahudi Grigori Zinoviyev'in (ö. 1936) yönetimi altına verilmiştir. ${ }^{9}$ Toplam 22 üyeden oluşan Halk Komiserleri Konseyi

Yahudi Mesihliğinin derinliklerinde yatmaktaydı. Marx'ın metodolojisi de tamamen Hahamlığa dayanıyordu. Paul Johnson, Yahudi Tarihi, çev.: Filiz Orman (Pozitif Yayınları, 2001), 417-420.

6 N. Berdyaev, Dostoyevski: Ruh Sürgünü, çev.: E. Gürol (İstanbul: Dünya Yayınc1lik, 2004), 78.

7 V. Moss, Orthodox Church at the Crossroads (1917-1999), İngilizceden çev.: T. A, Senina (Petersburg: 2001), 11-12.

8 Çalışmamızdaki veriler, Andrey Dikiy'in Rusya ve SSCB'de Yahudiler başlıklı çalışmasından aktarılmaktadır. Her ne kadar Dikiy, Yahudi karşıtlığı ile biliniyor ise de çalışmasında verdiği istatistikleri arşiv belgelerine dayandırmaktadır. 
yetkilisinden 17'si Yahudilerden müteşekkildi. Geri kalan 3'ü ki bunların başında Lenin, 1 Ermeni ve 1 de Gürcü bulunuyordu. Harp Komiserliğinde görev alan toplam 43 kişiden 35'i Yahudi, 7'si Letonyalı ve 1 de Alman bulunuyordu. İçişleri Bakanlığı bünyesinde toplam 62 üst düzey yöneticiden 43'ü Yahudi geri kalanlar ise diğer milletlerden oluşuyordu. Dışişleri Bakanlığ yönetim kadrosunu oluşturan 16 bürokrattan yine 13'ü Yahudi'ydi. Maliye Bakanlığ1 bünyesinde görev alan 29 üst düzey bürokrattan 24'ü Yahudi soy ismi taşımaktaydı. Adalet Bakanlığında görev alan 19 üst düzey bürokrattan 18'i Yahudi idi. Yine Eğitim Bakanlığında görevli toplam 53 üst düzey yöneticiden $42^{\prime}$ si Yahudilerden oluşmaktayd $1 .{ }^{10}$ Sovyetler Birliği Komünist Partisi Merkez Komitesinde görev alan üst düzey yetkiliden 61'i Yahudi soy ismi taşımaktaydı. Halk Komiserleri Konseyi bünyesinde mevcut 136 kişiden 115 'i, Dış İlişkiler ve Yurt Dış Ticaret Komiserleri toplam 131 üyeden 106'sı Yahudilerden oluşuyordu. Tüm Rusya Merkezi Yönetim Komitesi 22 kişiden müteşekkildi ve bunlardan 17 'si Yahudi soy ismi taşımaktaydi. Aydınlanma ve Militan Ateistleri Birliği; içindeki toplam 42 üyeden $40^{\prime} 1$ Yahudi kimliğine sahipti. ${ }^{11}$ Liste bu şekilde uzayıp gitmektedir. Araştırmacı G. Kostyrchenko, Stalin'in Gizli Politikası başlıklı çalışmasında 1926 yılı itibarıyla Sovyetler Birliği Komünist Partisi Merkez Komitesi bünyesinde mevcut toplam yetkilinin \%20'sini Yahudilerin oluşturduğunu yazmaktadır. Kostyrchenko'ya göre toplumun sosyo-politik hayatında Yahudi faktörünün bu denli etkin hale gelmesi, tepkileri de beraberinde getiriyordu. ${ }^{12} \mathrm{Bu}$ bilgileri teyit eder mahiyette bir diğer veriyi yine 1927 'deki XV. Komünist Partisi Kongresinde sunulan raporda görmek mümkündür. Grigol Orconikidze (ö. 1937) tarafından sunulan rapora göre, Moskova Sovyet Teşkilatının \%12'si, Ukrayna teşkilatının \%22,6'sı Belarus teşkilatının ise \%30,6'sı Yahudilerden oluşmaktaydı. ${ }^{13}$

1920'li yıllarda Sovyetlerde oluşan devlet bürokrasisi ile ilgili yukarıda verilen bilgilere ek olarak ekonomi alanında mevcut Yahudi etkinliğini de zikretmekte yarar vardır. 1926 yılı verilerine göre

\footnotetext{
Dikiy, Evreyi v Rossi i SSSR, 407-411.

Dikiy, Evreyi v Rossi i SSSR, 245.

G.V. Kostyrchenko, Taynaya Politika Stalina: Vlast i Antisemitizm (Moskova: 2003), 59.

13 Rabinovich Yakov, Bit Evreyem v Rossii: Spasibo Solojenitsinu, (Moskova: Algoritma, 2005), 237.
} 
ülkede faaliyet gösteren her beş tüccardan biri Yahudi'ydi. Moskova' da faaliyet gösteren eczanelerin $\% 75,4^{\prime} \ddot{u}$, parfümeri mağazalarının $\% 54,5$ 'i ve giyim mağazalarının $\% 48,6$ 'sı Yahudilerin elindeydi. Bu oran batı bölgelerinde çok daha yüksek çıkmaktadır. Örneğin Ukrayna'da ticaretin \%66'sı, Belarus'ta ise \%90'nı Yahudi tüccarların kontrolündeydi. Yahudilerin yoğun ilgi gösterdikleri bir diğer meslek ise zanaatkârlıktı ki bu alanda da Yahudi etkinliği \%40 civarındaydı. ${ }^{14}$ Görüldüğü üzere Sovyetlerin ilk yıllarında Yahudiler, Çarlık Rusya'sında olduğundan çok daha etkin bir biçimde ülkenin sosyo-politik ve ekonomik alanında rol oynamışlardır. İşte bu durum hem Çarlık Rusya'sında hem de Sovyetler Birliğinde toplumun Yahudilere karşı negatif tutum sergilemesine zemin oluşturmaktayd.

1930'lu yılların sonlarına doğru, Yahudilerin devlet kurumlarındaki mevcut etkinliklerinin kısmen azalmaya başladığ görülmektedir. Bu, Stalin diktatörlügünün iyiden iyiye kendini hissettirdiği dönemlere denk gelmektedir. Örneklendirmek gerekirse, 1935 yllında SSCB Merkez Yürütme Komitesi'ne seçilen 608 üyeden sadece 98 'i yani \%16'sı Yahudi'dir. Yine 1937 yılı SSCB Yüce Meclisini oluşturan 1143 üyeden sadece 47'si yani \%4'ü Yahudilerden müteşekkildir. Araştırmacı Yakov Rabinovich, devlet kurumlarında mevcut Yahudi sayısında yaşanan azalmayı 1930'lu yıllarda gerçekleştirilen devlet dairelerindeki Yahudi temizliğine bağlamaktadır. Nitekim söz konusu yıllarda yüz binlerce insan çeşitli suçlamalarla ya kurşuna dizilmiş ya da Sibirya'ya sürgün edilmiştir. Bunların arasında Tüm Rusya Merkezi Yönetim Komitesi üyesi Grigory Kaminsky, İçişleri Halk Komiserliği görevini yürüten Genrih Yagoda ve iç ticaretten sorumlu Arkady Rosengolts gibi ünlü Yahudi bürokratlar da bulunmaktadır. ${ }^{15}$ Yahudi etkinliğinin giderek azalma kaydettiğinin gözlemlendiği bir diğer alan ise Sovyetlerin en önemli kurumlarından biri olan İçişleri Halk Komiserliğidir. Zira 1936 yılına kadar kurumun \%41'i Yahudilerden müteşekkilken bu oran her geçen yıl azalma kaydetmiştir. Öyle ki 1937 yılında \%31'e ve 1939 yıl1nın son çeyreğine gelindiğinde ise \%4'e kadar gerilediği görülmektedir. ${ }^{16}$

14 Kostyrchenko, Taynaya Politika Stalina, 101.

15 Rabinovich, Byt Yevreyem v Rossii, 254.

16 Mikhail Tumshis, Yevrei v NKVD SSSR. 1936-1938 gg. Opyt Biograficheskogo Slovarya, (Russkiy Fond Sodeystviya Obrazovaniyu i Nauke: 2016), 10-22. 
1930'lu yılar sadece komünist Yahudi bürokratlar açısından değil aynı zamanda inançlı Yahudiler açısından da zorlukların yaşandığı bir dönem olmuştur. Öyle ki 1933 yılı sonu itibarıyla 257 sinagog ibadete kapatılırken, bu sinagoglarda görev yapan hahamlar ya idam edilmiş ya da sürgüne gönderilmiştir. Bu oran, Sovyetlerin iktidara geldiği 1920'li yıllarda faaliyet gösteren toplam sinagogların $\% 57$ 'sine tekabül etmektedir. Yine Yahudilerin Mısır'dan çıkışın anısına kutladıkları Pesah Bayramında tüketilmek üzere pişirdikleri mayasız ekmek için, 1929 yılı itibarıyla yüksek vergi getirilirken, 1937 yılı itibarı ile de üretimi tamamen yasaklanmıştır. ${ }^{17}$ Yahudi mabet ve din adamlarına yönelik bu uygulama aslında Sovyetlerin öteden beri Kilise temsilcilerine uyguladığı baskı ve sindirme politikasının bir devamı niteliğindedir. İktidara gelen Bolşevikler ilk olarak Ortodoks Kilise hiyerarşisini kendileri açısından bir tehdit olarak görmüşler ve onun ortadan kaldırılması için yoğun çaba harcamışlardır. ${ }^{18}$ Etki ve nüfus bakımından ikincil ve üçüncül konumda olan dini yapıların üzerine ise 1930 'lu yıllarda daha fazla gidildiği görülmektedir.

\section{Sovyet Toplumunda Giderek Artan Yahudi Karşıtlı̆ğ}

İmparatorluk nüfusunun \%5'ini oluşturan Yahudilerin devrimle birlikte oluşturulan yeni sistem içerisinde tüm stratejik kurumlarının \%80'ini kontrolü altına alması Rus toplumunda ciddi rahatsızlığa neden olmuştur. Bu durumun sıradan halk tarafından da takip edildiği, şu deyimden net bir biçimde anlaşılmaktadır; "çay sektörüYahudi Visochko'nun, şeker Yahudi Brodsko'nun, bütün Rusya ise Yahudi Troçki'nindir" ${ }^{19}$ Gerçekten de devrimin ilk yıllarında devlet kademelerinin önemli bir bölümünde Yahudilerin etkinliği ve ortaya çıan Sovyet yönetiminde Yahudi hegemonyasının inkâr edilemez olduğu bilinen bir gerçektir. Bu nedenle stratejik kurumların Yahudi kökenli bürokratların kontrolüne geçmesi, Rus toplumu içerisinde Yahudi karşıtlı̆̆ının yükselmesine neden olmuştur. Rabinovich'in de belirttiği gibi 1920'ler Yahudilerin devlet yönetiminde baskın oldukları dönemlerdir. Rus insanı daha önce zorunlu iskân sınırları içerisinde görmeye alışı olduğu Yahudilerle, artık devletin

\footnotetext{
17 Rabinovich, Byt Yevreyem v Rossii, s. 261.

18 Bu hususta geniş bilgi için bakınız: Şir Muhammed Dualı, Rusya'da Din-Devlet ilişkileri, İz Yayınları, İstanbul, 2014, s. 105-116.

19 Dikiy, Yevreyi v Rossii İ v SSSR, s.134.
} 
her kademesinde karşılaşmaktayd.$^{20} \mathrm{Bu}$ ise toplum nezdinde Yahudi algısının olumsuz yönde etkilenmesine zemin oluşturuyordu. Özellikle büyük kentlerde belirgin olan Yahudi karşıtlığı giderek toplum tabanına da yayılmaya yüz tutunca, Sovyetler Birliği Komünist Partisi Merkez Komitesi harekete geçti. 1928 yılı itibarıla bazı kararlar alan Sovyet Yönetimi, toplumda giderek alevlenen Yahudi karşıtlığının önüne geçmek maksadı ile eğitim programına anti-semitizm konusunu dâhil etti. Yine bu hususta halkın aydınlatılması için başta tiyatro ve sinema olmak üzere günlük gazete ve edebi neşriyatın aktif kullanılması kararlaştırıldı. Ayrıca oluşturulan bir komisyon bünyesinde Yahudi karşıtlığ ile mücadele maksadıyla özel eğitimli personelin istihdamına karar verildi. Lakin tüm bu tedbirler, Rus toplumu içerisinde mevcut Yahudi karşıtlığının önüne geçmeye yetmeyecektir. Örneğin Yahudi karşıtlığı hususunda halkın bilgilendirilmesi maksadıyla 1928 yılında Moskova' da gerçekleştirilen bir toplantıda katılımcılar, Yahudilerin ağır işlerde çalışmaktan kaçınması, her zaman masa başı işlerde görev almaları ve devletin Yahudilere iyi araziler tahsis etmesi hususunda duydukları rahatsızlı̆̆ 1 dile getirmişlerdir. ${ }^{21}$

Yahudilerin ön plana çıtıkları yerlerden bir diğeri de eğitim ve öğretim alanıydı. Örneğin 1927-1928 eğitim öğretim yılı içerisinde SSCB'de eğitim veren yükseköğretim kurumlarında öğrenim gören toplam öğrencilerin \%12,2'sini Yahudiler oluşturmaktaydı. Bu 3 milyon civarındaki toplam Yahudi nüfusu göz önünde bulundurulduğunda oldukça büyük bir orana tekabül etmektedir. Ayrıca Yahudi öğrencilerin tercih ettikleri branşlar da dikkat çekmektedir. İlk sırada \%31'lik oranla iktisadi ve ticari fakülteler gelirken onu $\% 28$ 'ile tıp fakülteleri takip etmektedir. ${ }^{22} \mathrm{Bu}$ verilere göre 1930'lu yıllarda SSCB'de faaliyet gösteren her dört doktordan biri Yahudi'ydi. Rabinovich, 1920 ile 1930 yılları arasında Sovyet yönetiminin bilinçli bir biçimde İbranice (Yidiş) eğitim veren okulları yaygınlaştırdığını ifade etmektedir. ${ }^{23}$ Şöyle ki 1923 yılında 70 bin öğrencisi ile 495 İbrani Okulu eğitim faaliyeti gerçekleştirirken, bu sayı 1930 yılı içerisinde 160 bin Yahudi çocuğunun eğitim gördüğü 900 okula

20 Rabinovich, Byt Yevreyem v Rossii, 235.

21 Dikiy, Evreyi v Rossi i SSSR, 152-155.

22 Kostyrchenko, Taynaya Politika Stalina, 101.

23 Simcha Fishbane, "The Bolshevik Revolution and Communism", The Encyclopaedia of Judaism, Second Edition, IV (Boston, 2005), 2336. 
kadar yükselmiştir. ${ }^{24}$ İzlenen bu politikanın doğal sonucu olarak Sovyet Yükseköğretim Kurumlarında Yahudi öğrenci sayısı yukarıda belirtilen oranlara kadar çıkmayı başarmıştır. 1930'lu yılların ortalarından itibaren ise Yidiş okullarının sayısı giderek azalmaya başlamış ve nihayet 1938 yılında yapılan bir düzenleme ile tüm Yidiş okulları kapatılmıştır. Yahudi Ansiklopedisine göre bu, Stalin'in uyguladığı baskıcı politikaların bir sonucu ve Sovyet hükümetinin ulusal kültürlere yönelik tutumundaki değişikliğin bir yansımasiydi. ${ }^{25}$

1930'lu yıllardan itibaren Sovyet yönetiminin kollektifleştirme politikalarını hayata geçirmesi ile birlikte Yahudi karşıtlığında görünürde bir azalma olduğu müşahede edilmektedir. Bunun nedeni Yahudi lobisinin Sovyet hükümeti üzerinde oluşturduğu baskıdır. Amerika'da bulunan Yahudi lobisinin, Sovyetlerde mevcut anti-semitizm üzerine yazılar yayınladığı ve bu meseleyi gündemde tuttuğu görülmektedir. 1939 yılında Semyon Osipovich Portugheis (ö.1944) "Yahudiler ve Sovyet Diktası" başlıklı makalesinde bu hususa dikkat çekmekte ve sanıldığının aksine Sovyetler Birliğinde anti-semitizmin çok daha yaygın olduğunu dile getirmektedir. Portugheis, Sovyet Yahudilerinin korku içerisinde bulunduklarını, halkın Stalin korkusu olmasa, sürecin pogromlara kadar gideceğini, Sovyetler Birliğinin düşmesi halinde ise Yahudilerin bir facia yaşayacakların belirtmektedir. ${ }^{26}$ Portugheis ve benzeri Yahudi yazarların ortaya koydukları bu endişenin haklı nedenleri vardır. Hatırlanacağı üzere Çarlık Rusya'sında Yahudiler uzun yıllar boyunca k1yımlara maruz bırakılmışlardı.

\section{III. Çözüm Arayışları: Yahudi Özerk Bölgesinin Oluşturulması}

18. yüzyıldan itibaren Rus Devlet sınırları içerisinde varlık göstermeye başlayan yüzbinlerce Yahudi, genellikle kent ve kasabalarda ikamet etmişler ve daha fazla ticaretle meşgul olmuşlardır. Ancak Sovyet Birliği'nin oluşturulması ile birlikte, ortaya konulan tarım politikaları, 3 milyon civarındaki Yahudi'nin bu alanda da istihdam edilmesini zorunlu kılmaktaydı. Bu çerçevede 24 Ağustos 1924 tarihinde oluşturulan Yahudi İş̧̧iler Arazi Sistemi Komitesi bünyesinde Yahudi İş̧ilerin Toprak Yönetimi adında bir dernek faaliyete geçirildi. Sovyet bürokrasisindeki Yahudilerin öncülügüünde yürütülen bu

24 Rabinovich, Byt Yevreyem v Rossii, 238.

25 Simcha, "The Bolshevik Revolution and Communism", 2336

26 Dikiy, Evreyi v Rossi i SSSR, 160. 
proje ile büyük ölçekli birinci sınıf araziler Yahudilere tahsis edilecekti. Bu vesile ile Yahudilerin tarım işlerine yönlendirilmesi sağlanacaktı. Bu çerçevede sadece Kırım Yarımadasında 342 bin hektar, Ukrayna Sovyet Sosyalist Cumhuriyeti sınırları içerisinde 175 bin hektar tarım arazisi Yahudilere tahsis edildi. Bu projenin başını çeken Yahudi bürokratlar, Yahudilerin de diğer uluslar gibi bir özerk bölgeye sahip olmasını amaçliyorlardı. Bunun için Yahudilerin yoğunlukta yaşadığı Kırım ve Ukrayna'nın güney kesiminde bir özerk Yahudi bölgesinin oluşturulması üzerine çalışma başlatıldı. Bu projeye başta Yahudi Troçki olmak üzere, Lev Kamenev ve Nikolai Bukharin gibi üst düzey Sovyet politikacılar da güçlü destek veriyorlardı. Ancak Kırım projesi bürokrasi içerisinde ciddi muhalefetle karşı karşıya kaldı. Muhaliflerin başını, Rusya Sovyet Federatif Sosyalist Cumhuriyeti Tarım Komiseri Başkanı Aleksandr Petrovich Smirnov (ö. 1938) çekmekteydi. Smirnov, bu uygulamanın diğer halklara karşı bir eşitsizlik anlamına geleceğini ve bu durumun da Yahudi karşıtlığını körükleyeceğini ileri sürerek projeye karşı çıkıyordu. Smirnov'un düşüncesi Ukraynalı parti yöneticilerce de desteklendi. VIII. Tüm Ukrayna Parti Kongresinde konuşan yetkililer, Yahudilerin bir çatı altında belirli bir yere toplanmasının maksada uygun olmadığı ve bu tutumun Siyonizm'i anımsattığı üzerinde durdular. Ancak Yahudi etkisinde olan Sovyet yönetimi bu meseleyi gündemde tutmaya ve bu hususta adımlar atmaya devam etti. Dönemin Sovyet Sosyalistleri Birliği Dışişleri Halk Komiseri Georgy Vasilyevich Chicherin (ö. 1936), Berlin'de Yahudi topluluğu ile gerçekleştirdiği görüşmede Kırım projesini gündeme getirerek Sovyetlerin Yahudilere olan desteğine vurgu yapacaktır. ${ }^{27}$

Kırım Yarımadasında bir Yahudi özerk bölgesinin oluşturulması fikri, bölgenin asli unsurları olan Kırım Tatarlarını da son derece rahatsız etmekteydi. Zira bu hususa Smirnov da temas etmekte ve Tatarların rahatsızlığını dile getirmekteydi. Sonuç olarak bölge halklarının ve bürokraside oluşan muhalefetin itirazları neticesinde Kırım projesinden vazgeçen Sovyet yönetimi, yeni bir proje üzerinde yoğunlaşma kararı aldı. Bu Çin sınırına yakın bir bölgede 4 milyon hektarlık bir alanda Yahudi Ulusal Bölgesi'nin oluşturulması projesiydi. Bu fikir Sovyet bürokrasisi içerisinde kabul gördü ve 1930 yılı itibarıyla bölgeye özerklik statüsü tanındı.. ${ }^{28} 1934$ yılında

27 Kostyrchenko, Taynaya Politika Stalina, 93-97.

28 Dikiy, Evreyi v Rossi i SSSR, 191. 
ise il statüsüne yükseltilen Özerk Yahudi Ulusal Bölgesinde Birobican adı ile yeni bir şehir inşa edilmiş oldu. Bir Yahudi bölgesi olarak tesis edilen Birobican'da eğitim dili ve gazete yayınlarının İbranice (Yidiş) yapılmasının de önü açılmış oldu. Her ne kadar Sovyet yönetimi bölgeye özerklik statüsü tanıyarak burayı bir Yahudi yerleşim yeri olarak tescillediyse de Birobican'a olan Yahudi ilgisi son derece düşük düzeylerde kaldı. Örneğin 1930'lu yılların sonlarında bölgeye gelen toplam Yahudi sayıs 20 bin civarındadır. Sovyet s1nırları içerisinde mevcut 3 milyon Yahudi nüfus düşünüldügünde bu sayının son derece az olduğu anlaşılacaktır. Yahudilerin Özerk Yahudi Ulusal Bölgesi'ne rağbet etmeyişlerinin temel nedeni, bölgenin tarım dışında diğer olanaklara pek imkân sunmayışıdır. Yine de Sovyet tarım politikaları kapsaminda belirli sayıda Yahudi, bu alanda istihdam edilebilmişti. Örnek verecek olur isek, 1913 verilerine göre tarım işi ile meşgul olan toplam Yahudi sayısı 52 binin üzerinde iken bu sayı, 1924 yılında 100 bine çıkmaktadır. Sadece 19251928 yılları arasında Yahudileri tarım işçiliğine yönlendirmek amacıyla 22 milyon rublenin harcandığı bilinmektedir. ${ }^{29}$ Ancak Yahudiler açısından tarım ile uğraşmak pek de karlı bir iş olarak görülmediğinden onlar başta Moskova olmak üzere ülkenin büyük kentlerinde ticaret ve zanaatkârlık ile meşgul olmayı tercih etmekteydiler. $\mathrm{Bu}$ nedenle Yahudiler, kendilerine yönelik kısitlamaların kaldırıldığ 1 1917'den itibaren büyük kentlere akın etmişlerdi. Örneğin 1920 yılında Moskova'da 28 bin Yahudi mevcut iken bu sayı 1926 yılında 131 bine, 1933 yılında ise 226 bine yükselmişti. ${ }^{30}$ Alınan tüm tedbirlere rağmen, Yahudileri tarım alanına yönlendiremeyen Sovyet yönetimi 1938 yılında Yahudi İşçiler Arazi Sistemi Komitesini ilga etmek mecburiyetinde kaldı. Yahudi Özerk Bölgesi olan Birobican'a yönelik Yahudi ilgisinin de her geçen yıl daha da azaldığı gözlemlendi. Örneğin 1959 verilerine göre Özerk Yahudi Ulusal Bölgesi'nin toplam nüfusu 162 bin civarındadır. Bunlardan 127 bini Rus, 4 bini Ukraynalı ve sadece yaklaşı 4 bini Yahudi'ydi. ${ }^{31}$ Sonuç olarak, Yahudi etkisindeki Sovyet bürokrasisinin Yahudilere yönelik bir özerk bölge oluşturma girişimi, yine Yahudilerin ilgisizliği sonucu istenilen neticeyi vermeyecekti. Bu sonuç, Rusya'da Yahudi karşıtlı̆̆ının

\footnotetext{
Kostyrchenko, Taynaya Politika Stalina, 98.

Rabinovich, Byt Yevreyem v Rossii, 236.

Dikiy, Evreyi v Rossi i SSSR, 196.
} 
neden hiçbir zaman son bulmadığını, Yahudilerin niçin ağır işlerden kaçınmakla suçlandığını, açıkça ortaya koymaktadır.

\section{Sonuç}

Hıristiyanlığın Ortodoks mezhebine mensup Rusların öteden beri Yahudiler ile sorunlu bir ilişki içerisinde olduklarını söylemek mümkündür. Bu sorunların büyük kıyım ve katliamlara dönüştüğü dönem ise 19. yüzyılın son çeyreğidir. Bünyesinde milyonlarca Yahudi'yi barındıran Çarlık rejiminin uyguladığı asimilasyon politikaları, zamanla Yahudi toplumunun kendi içinde veya çeşitli işçi ve anarşik gruplar bünyesinde örgütlenmesine yol açmıştır. 1917 Şubat devrimini müteakiben oluşturulan Geçici Hükümetin 21 Mart 1917 tarihi itibarıyla Yahudilere yönelik daha önce uygulanan tüm kısıtlamaları ortadan kaldırması, Yahudilerin başta siyaset olmak üzere çeşitli alanlarda faaliyetlerde bulunmalarının da önünü açmıştır. İşte ilk dönem Sovyet bürokrasisi içerisinde yüzlerce Yahudi'nin yer almasının temelinde, Yahudilerin yıllardan beri çok güçlü bir şekilde örgütlenmiş olmaları yatmaktadır. Yahudilerin bu etkinliğinden dolayıdır ki bazı araştırııılar, Bolşevik Devrimini haddizatında bir Yahudi devrimi olarak telakki etmişlerdir. Bu sebepten dolayı, Sovyetlerin ilk dönemlerinde Rus toplumundaki Yahudi karşıtlığında yeniden bir canlanmanın olduğunu görmek mümkündür. Toplumda giderek artan Yahudi karşıtlığını önlemek adına çeşitli girişimlerde bulunan Sovyet yönetimi, çözümü Yahudi Özerk bölgesinin oluşturulmasında bulmuştur. Devletin karar mekanizmalarında söz sahibi olan Yahudi siyasilerin de etkisi ile başta Kırım Yarımadası, Yahudi Özerk Bölgesi olarak düşünülmüşse de bu, Kırım Tatarlarının ve bazı Ukraynalı siyasilerin direnci nedeniyle Çin sınırında gerçekleştirilmiştir. Sovyetler Birliği içerisinde yer alan tüm milletlerin olduğu gibi, Yahudilerin de bir özerk bölgesinin olması maksadıyla gerçekleştirilen bu girişim, tüm çabalara rağmen istenilen neticeyi vermemiştir. Bunun temel nedeni, söz konusu bölgenin tarıma dayalı bir yaşam tarzı sunuyor olmasıdır. Oysa Yahudiler, daha ziyade büyük kentlerde yaşamayı, ticaret, sanat ve akademiyle iştigal etmeyi tercih etmişlerdir. $\mathrm{Bu}$ ise Sovyetlerin öngördüğü Özerk Yahudi Bölgesi planının başarısızlıkla sonuçlanmasına yol açmıştır. 


\section{Kaynakça}

Berdyaev, Nikolay. Dostoyevski: Ruh Sürgünü. Çev. E. Gürol. İstanbul: Dünya Yayınc1lık, 2004.

Dikiy, Andrey. Yevreyi v Rossii İ v SSSR, Russko-Yeveyskiy Dialog. Blagovest. Novosibirsk: 2005 (Дикий Андрей, Евреи в России и в СССР, Новосибирск).

Dualı, Şir Muhammed. Rusya'da Din-Devlet ilişkileri. İstanbul: İz Yayınları, 2014.

Fishbane, Simcha. "The Bolshevik Revolution and Communism". The Encyclopaedia of Judaism. Second Edition. IV. Boston: 2005.

Gennadiy, V. Kostyrchenko. Taynaya Politika Stalina: Vlast i Antisemitizm. Moskova: 2003 (Геннадий Костырченко, тайная подитика сталина; власть и антисемитизм, Москва, 2003).

Mikhail, Tumshis. Yevrei v NKVD SSSR. 1936-1938 gg. Opyt Biograficheskogo Slovarya. Russkiy Fond Sodeystviya Obrazovaniyu i Nauke, 2016 (Михаил Тумшис, Вадим Золотарёв, Евреи в НКВД СССР. 19361938 гг. Опыт биографического словаря, 2016).

Johnson, Paul. Yahudi Tarihi. Çev. Filiz Orman. Pozitif Yayınları, 2001.

Rabinovich, Yakov. Bit Evreyem v Rossii: Spasibo Solojenitsinu. Moskova: Algoritma, 2005 (Рабинович Яков, Бит Евреям в России; Спасибо Соложеницину, Москва, 2005).

Simcha, Fishbane. "The Bolshevik Revolution and Communism". The Encyclopaedia of Judaism. Second Edition. IV. Boston: 2005.

Moss, Vladimer. Orthodox Church at the Crossroads (1917-1999). İngilizceden Çev. T. A. Senina. Petersburg: 2001.

Yitzhak, Arad. Katastrofa Evreev na Okkupirovannıkh Territoriyah Sovetskogo Soyuza (1941-1954). Tom I. Tsentr Holokost. Moskova: 2007 (Ицхак Арад, Катастрофа евреев на оккупированных территориях Советского Союза, 1941-1945, Ткума, 2007). 